Tropical Journal of Pharmaceutical Research September 2015; 14 (9): 1581-1588

ISSN: $1596-5996$ (print); 1596-9827 (electronic)

(C) Pharmacotherapy Group, Faculty of Pharmacy, University of Benin, Benin City, 300001 Nigeria.

All rights reserved.

Available online at http://www.tjpr.org

Original Research Article

http://dx.doi.org/10.4314/tjpr.v14i9.6

\title{
Role of Glycol Chitosan-incorporated Ursolic Acid Nanoparticles in the Treatment of Osteosarcoma
}

\author{
Xing-Lin Zhang ${ }^{1,2}$, Xing Lu $^{2}$, Wei Geng ${ }^{3}$, Gao-Wei $Q u^{2}$, Zhi-Yong Zhou ${ }^{2}$, Lian- \\ Hong Jiang ${ }^{4}$, Yun-Xiang Li ${ }^{2}, \mathrm{Xu} \mathrm{Chen}^{2}$ and Lin-Nie ${ }^{5 *}$ \\ ${ }^{1}$ Department of Orthopedics, Qilu Hospital of Shandong University, Jinan 250012, ${ }^{2}$ Department of Orthopedics, Yantaishan \\ hospital, Yantai, Shandong, 264001, ${ }^{3}$ Department of Spine Surgery, Liaocheng People's Hospital, Liaocheng, Shandong \\ Province, 252000, ${ }^{4}$ Department of Radiology, Yantaishan hospital, Yantai, Shandong, 264001, ${ }^{5}$ Department of Spine Surgery, \\ Qilu Hospital of Shandong University, Jinan 250012, China
}

${ }^{*}$ For correspondence: Email: mdnielin14@gmail.com; Tel/Fax: 0086-531-82169114

\begin{abstract}
Purpose: To investigate the effect of ursolic acid (UA)-incorporated glycol chitosan (GC) nanoparticles on inhibition of human osteosarcoma.

Methods: U2OS and Saos-2 osteosarcoma cells were transfected with ursolic acid (UA) incorporated glycol chitosan (GC) nanoparticles. Ultraviolet (UV) spectrophotometry was used to measure drug contents in nanoparticles at $365 \mathrm{~nm}$ with empty GC vehicles as blank. Bicinchoninic acid assay (BCA) method was employed to determine protein concentration. Identification of apoptosis and necrosis in osteosarcoma cells was performed by propidium iodide and FITC-annexin V reagents, respectively. FAC Scan flow cytometry was used to analyse apoptotic cells.

Results: Among the range of UA concentrations tested, the minimum effective concentration was 10 $\mu M$ with half inhibitory concentration IC $C_{50}$ of $25 \mu M$. In U2OS cells, treatment with 10 and $25 \mu M$ UAinduced apoptosis in $5.89 \pm 3.90$ and $60.54 \pm 5.40 \%$ cells, respectively, compared to $2.05 \pm 1.01 \%$ cells for control. In Saos-2 cells, exposure to 10 and $25 \mu M$ UA induced apoptosis in $9.86 \pm 8.89$ and $47.54 \pm 14.5 \%$ cells, respectively, compared to $1.79 \pm 0.23 \%$ for control cells. Western blot analysis revealed translocation of Bax and Bcl-2 proteins from mitochondria to cell cytosol. Increase in UA concentration from $10 \mu \mathrm{M}$ to $25 \mu \mathrm{M}$ led to increase in the proportion of cells in G0/G1 phase and decrease in the number of cells in S and G2/M phases. These results confirm that UA transfection arrests cell cycle in G0/G1 phase in human osteosarcoma cell lines.

Conclusion: UA transfection resulted in the inhibition of cell proliferation, Ezh2 expression inhibition, and apoptosis via mitochondrial pathway due to decrease in membrane potential and release of cytochrome C, as well as cell cycle arrest in G0/G1 phase.
\end{abstract}

Keywords: Osteosarcoma, Cell cycle arrest, Palliation, Glycol chitosan, Ursolic acid

Tropical Journal of Pharmaceutical Research is indexed by Science Citation Index (SciSearch), Scopus, International Pharmaceutical Abstract, Chemical Abstracts, Embase, Index Copernicus, EBSCO, African Index Medicus, JournalSeek, Journal Citation Reports/Science Edition, Directory of Open Access Journals (DOAJ), African Journal Online, Bioline International, Open-J-Gate and Pharmacy Abstracts

\section{INTRODUCTION}

Osteosarcoma, a common primary bone sarcoma has a 5-year survival rate of $\sim 70 \%$ in children and adolescents [1]. Patients with osteosarcoma have a poor prognosis, with overall survival rates of $<20 \%$ [1].
Osteosarcoma is a well-defined clinical entity with a characteristic radiographic appearance, histologic features, a relatively consistent spectrum of clinical presentations, and established standard treatments. These features have been the subject of many prior book chapters and reviews [2-7]. However, all the 
present treatments are less efficient. Therefore, the discovery of molecules with roles in the osteosarcoma inhibition is highly desired to improve the clinical treatment.

Polycomb group genes (PcG) which are involved epigenetically in regulating gene transcription programs during development and cellular differentiation [8] harbor a catalytic subunit, Enhancer of Zeste homolog 2 (Ezh2). Knowledge regarding tumor stem cells has demonstrated that Ezh2 similarly controls expansion and differentiation of tumor initiating cells [9] and plays an important role in the development and progression of cancer $[10,11]$. Myelodysplastic syndromes involving inhibition mutations in Ezh2 gene proves that Ezh2 functions as a tumor suppressor [12,13]. Ezh2 inhibits cell differentiation to maintain stemness of tumor cells $[14,15]$.

Triterpenes and their derivatives have been reported to possess activities such as anti-HIV [16-19], inhibition of HIV protease [20] and cytotoxicity to tumor cell lines [21,22]. Ursolic acid (Fig 1), a pentacyclic triterpene isolated in abundance from the peels of Malus pumila Mill has been reported to possess a wide range of pharmacological properties, including antiinflammatory, antiallergic, antibacterial, antiviral, antitumor and cytotoxic activities being the most intriguing. Owing to its biological potential, it was ranked as one of the most promising tumorpreventive medications by Japanese researchers [17]. Mechanistic studies revealed that ursolic acid blocks the cell cycle progression in $G 1$ phase and its treatment results in the triggering of apoptosis as determined by DNA fragmentation assay. Despite its in vitro biological promise, its poor bioavailability under in vivo restricts its clinical applications. One of the techniques to improve the bioavailability of this molecule is the development of polymeric micelles, like glycol chitosan micelle. In the present study effect of UA-incorporated glycol chitosan nanoparticles on osteosarcoma were investigated.

\section{EXPERIMENTAL}

\section{Cell culture}

Human osteosarcoma cell lines, U2OS and Saos-2 were purchased from the Health Science Research Resources Bank (Osaka, Japan). The cells were maintained in RPMl 1640 medium (RPMI: ECM $=4: 1$ ) supplemented with $10 \%$ fetal bovine serum at $37{ }^{\circ} \mathrm{C}$ in $5 \% \mathrm{CO}_{2}$ in a humidified atmosphere.

\section{Chemicals and reagents}

Glycol chitosan (GC), ursolic acid (UA), dialysis membranes (MWCO $=12,000 \mathrm{~g} / \mathrm{mol}$ ) and propidium iodide $(\mathrm{PI})$ were purchased from Sigma Chem. Co. Ltd. (St. Louis, MO, USA).

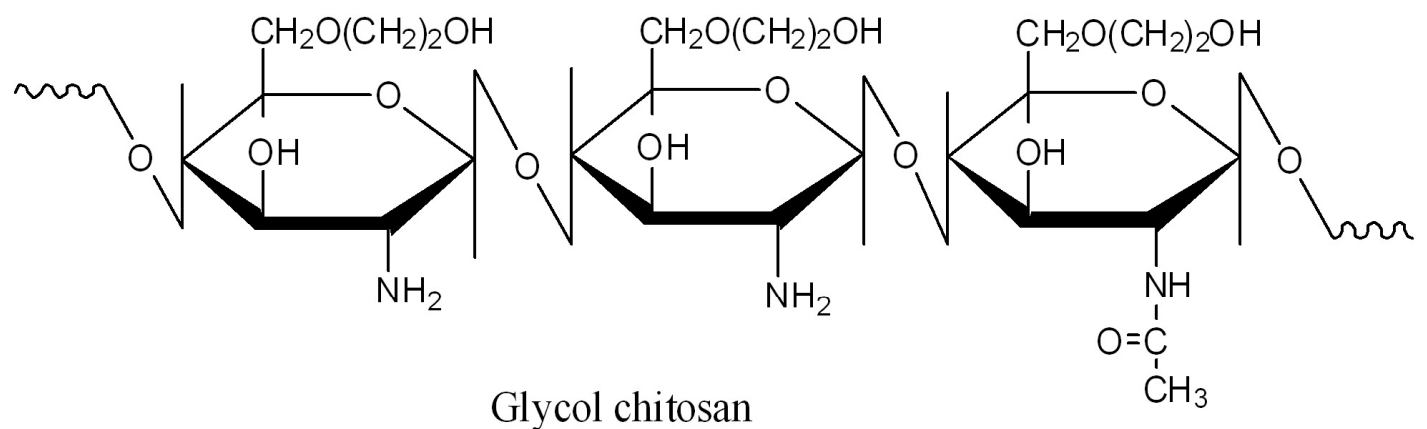<smiles>C[C@H]1CCC2(C(=O)O)CC[C@]3(C)C(=CCC4[C@@]5(C)CC[C@@H](O)C(C)(C)[C@@H]5CC[C@]43C)C2[C@@H]1C</smiles>

Ursolic acid

Fig 1: Structure of ursolic acid (UA) and glycol chitosan (GC) 
FITC-annexin V was obtained from Santa Cruz, CA, 95060, USA. This study was approved by the Institutional Review Board and Ethics Committee of the Nanjing University, Jiangsu, China.

\section{Preparation of UA-incorporated GC nanoparticles}

The UA-incorporated GC nanoparticles were prepared by adding a solution containing $5 \mathrm{mg}$ $\mathrm{UA}$ in $1 \mathrm{~mL}$ of DMF to an aqueous solution containing $40 \mathrm{mg}$ of $\mathrm{GC}$ in $10 \mathrm{~mL}$ of de-ionized water. The solution was stirred for $20 \mathrm{~min}$ at room temperature in a dark room. A dialysis membrane was used to prepare dialyzed solution against deionized water by dialysis for 1 day. Out of $20 \mathrm{~mL}$ prepared by adding deionized water to the dialyzed solution, $100 \mu \mathrm{L}$ was diluted with 9.9 $\mathrm{mL}$ of DMSO. The absorbance was measured at $365 \mathrm{~nm}$ using UV spectrophotometer (UV-1200, Shimadzu Co. Ltd., Kyoto, Japan) and compared with empty GC vehicles used as blank.

\section{Cell proliferation inhibition assay (MTT assay)}

In each well of a 96-well plate, aliquots containing $2.5 \times 10^{5}$ cells were seeded. The cells were incubated overnight in a $5 \% \mathrm{CO}_{2}$ incubator at $37{ }^{\circ} \mathrm{C}$ and then UA-incorporated GC nanoparticle solution was added to each well. After dilution with RIMI 1640 (10\% FBS), these were used to treat the tumor cells. RIMI 1640 (10 $\%$ FBS) with $0.1 \%(\mathrm{v} / \mathrm{v})$ DMSO was used as control. Incubation for $48 \mathrm{~h}$ at $37^{\circ} \mathrm{C}$ was followed by addition of $25 \mu \mathrm{L}$ of MTT ( $3 \mathrm{mg} / \mathrm{mL}$ in PBS) to each well and incubation was continued for $4 \mathrm{~h}$. To each well was added $100 \mu \mathrm{L}$ of SDS- $\mathrm{HCl}$ solution (SDS $10 \% \mathrm{w} / \mathrm{v}, 0.01 \mathrm{M} \mathrm{HCl}$ ) and incubated again for $12 \mathrm{~h}$. An Infinite M200 pro reader (Tecan Austria GmbH, Salzburg, Austria) was used to measure the absorbance at $570 \mathrm{~nm}$. The viable cells were expressed as percentage of control and all the experiments were conducted in triplicate.

\section{Western blotting}

The UA-GC nanoparticle treated osteosarcoma cells were washed twice in PBS followed by addition of Lysis buffer (50 mM Tris- $\mathrm{HCl} \mathrm{pH} 7.4$, containing $137 \mathrm{mM} \mathrm{NaCl}, 10 \%$ glycerol, $100 \mathrm{mM}$ sodium vanadate, $1 \mathrm{mM}$ PMSF, $10 \mathrm{mg} / \mathrm{ml}$ aprotinin, $10 \mathrm{mg} / \mathrm{ml}$ leupeptin, $1 \% \mathrm{NP}-40$, and 5 $\mathrm{mM}$ cocktail). Bicinchoninic acid assay (BCA) method was used to determine protein concentration. Equal amounts of protein were loaded and resolved by electrophoresis on a 10
$\%$ polyacrylamide gel. The semi-dry method was used to transfer proteins onto a PVDF membrane which was then blocked with $5 \%$ non-fat dry milk overnight. After TBST washing, the membrane was incubated for $2 \mathrm{~h}$ with primary antibodies and then washed again with TBST before incubation with secondary antibodies for $2 \mathrm{~h}$. The $x$-ray autoradiography was performed and the gray scale images analysed using Biolmaging System (UVP, USA).

\section{Flow cytometric analysis}

Identification of apoptosis and necrosis in osteosarcoma cells was carried out using propidium iodide and FITC-annexin $\mathrm{V}$ reagents respectively. Treatment of cells with various concentrations of UA-incorporated GC nanoparticles for $24 \mathrm{~h}$ was followed by washing with PBS. After suspension in binding buffer (10 $\mathrm{mM}$ HEPES $\mathrm{pH}$ 7.4) containing $150 \mathrm{mM} \mathrm{NaCl}, 5$ $\mathrm{mM} \mathrm{KCl}, 1 \mathrm{mM} \mathrm{MgCl}$, and $1.8 \mathrm{mM} \mathrm{CaCl}_{2}$ ) and FITC annexin $V(1 \mu \mathrm{g} / \mathrm{mL})$, the pellets were incubated for $20 \mathrm{~min}$. PI $(10 \mu \mathrm{g} / \mathrm{mL})$ was added to stain necrotic cells under dark conditions and incubation was continued for $10 \mathrm{~min}$ more. FAC Scan flow cytometer (Becton Dickenson Biosciences, San Jose, CA, USA) was used to analyse the cells.

\section{Detection of single-strand DNA (ssDNA)}

In a 96-multiwell plate, 10000 cells/well were seeded and incubated with the UA-incorporated GC nanoparticles. The cells were then fixed with $80 \%$ methanol for $30 \mathrm{~min}$. The plates were dried and incubated with formaldehyde for $10 \mathrm{~min}$ at room temperature followed by $10 \mathrm{~min}$ at $75{ }^{\circ} \mathrm{C}$, and then at $4{ }^{\circ} \mathrm{C}$ for $5 \mathrm{~min}$. With $3 \%$ non-fat dry milk cells were incubated for $1 \mathrm{~h}$ followed by incubation with the antibody mixture (containing a primary monoclonal antibody to ssDNA and horseradish peroxidase-labeled secondary antibody) for $30 \mathrm{~min}$. The addition of 2-2'-azinobis[3-ethylbenziazoline-6-sulfonic acid] solution permitted the reading of the plates at $405 \mathrm{~nm}$ in a standard microtiter reader. The SsDNA and necrotic cells obtained by hyperthermia were used as positive and negative control, respectively.

\section{Statistical analysis}

Statistical analysis was performed using Student's t-test with the aid of SPSS 16.0 statistical software, and the differences were considered statistically significant at $p<0.05$. Data are presented as mean \pm standard (SD). 


\section{RESULTS}

\section{Inhibition of proliferation of human osteosarcoma cells}

The results from MTT assay revealed a dosedependent inhibition of the U2OS and Saos-2 cell proliferation on UA treatment after $24 \mathrm{~h}$. Among the range of concentrations ( 5 to $50 \mu \mathrm{M}$ ) tested, the inhibition was significant at $10 \mu \mathrm{M}$ with a reduction in O.D. values of $16 \pm 0.6$ and $13 \pm 0.8 \%$ for U2OS and Saos-2 cell lines respectively. The reductions in absorbance for 20,30 and $40 \mu \mathrm{M}$ were $23 \pm 2,63 \pm 3.5,90 \pm 10$ $\%$ for Saos-2 and $36 \pm 3.2,64 \pm 3.43$ and $89 \pm$ $10.34 \%$ for Saos- 2 cells respectively. The $\mathrm{IC}_{50}$ values of UA were $24.2 \pm 2.8 \mu \mathrm{M}$ for U2OS cells and 23.9.1 $\pm 2.16 \mu \mathrm{M}$ for Saos-2.
Daily MTT data using $25 \mu \mathrm{M}$ UA for 4 days show that growth inhibition of both the cell lines was maximum on day 4 (Fig. 2A,B).

\section{Inhibition of Ezh2 expression in human osteosarcoma cells}

The results showed a significant decrease in Ezh2 expression level after $24 \mathrm{~h}$ of UAincorporated GC nanoparticles (25 $\mu \mathrm{M})$ transfection compared to control. The Ezh2 inhibition by UA lasted for at least $72 \mathrm{~h}$ after the UA-incorporated GC nanoparticle transfection (Fig. 3). These results suggest that after the transfection of the UA at $25 \mu \mathrm{M}$ for $24 \mathrm{~h}$, the Ezh2 and protein expression levels were effectively inhibited.
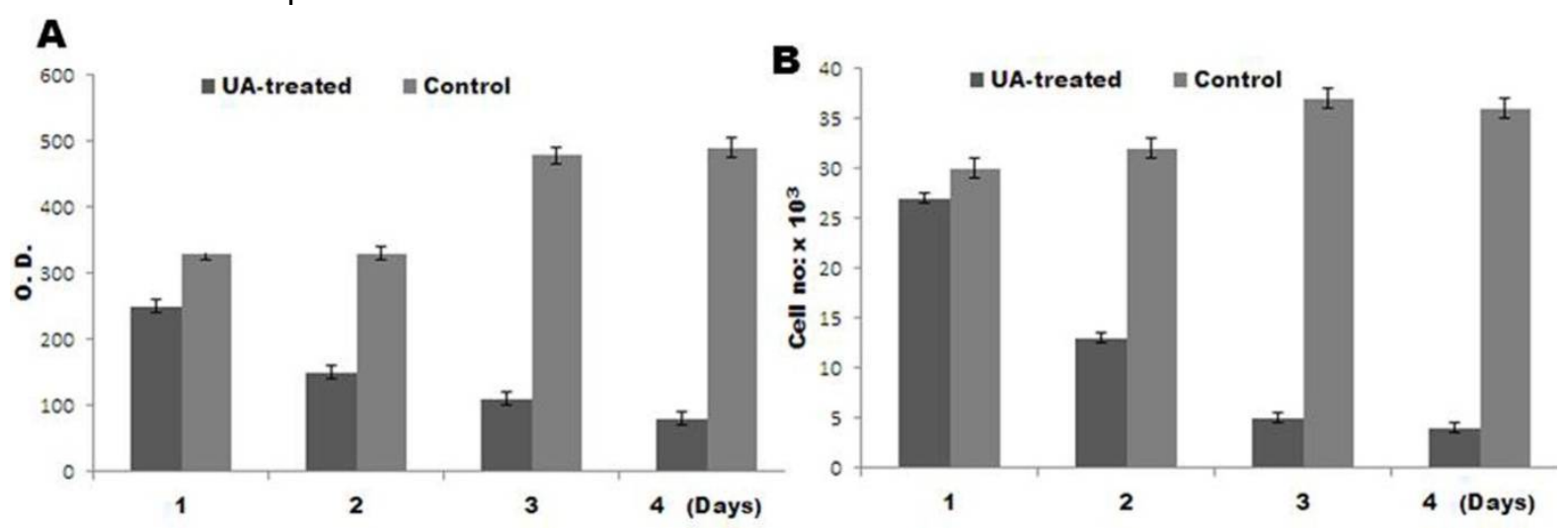

Fig 2: UA-incorporated GC nanoparticles induced time-dependent inhibition of U2OS and Saos-2 cell proliferation

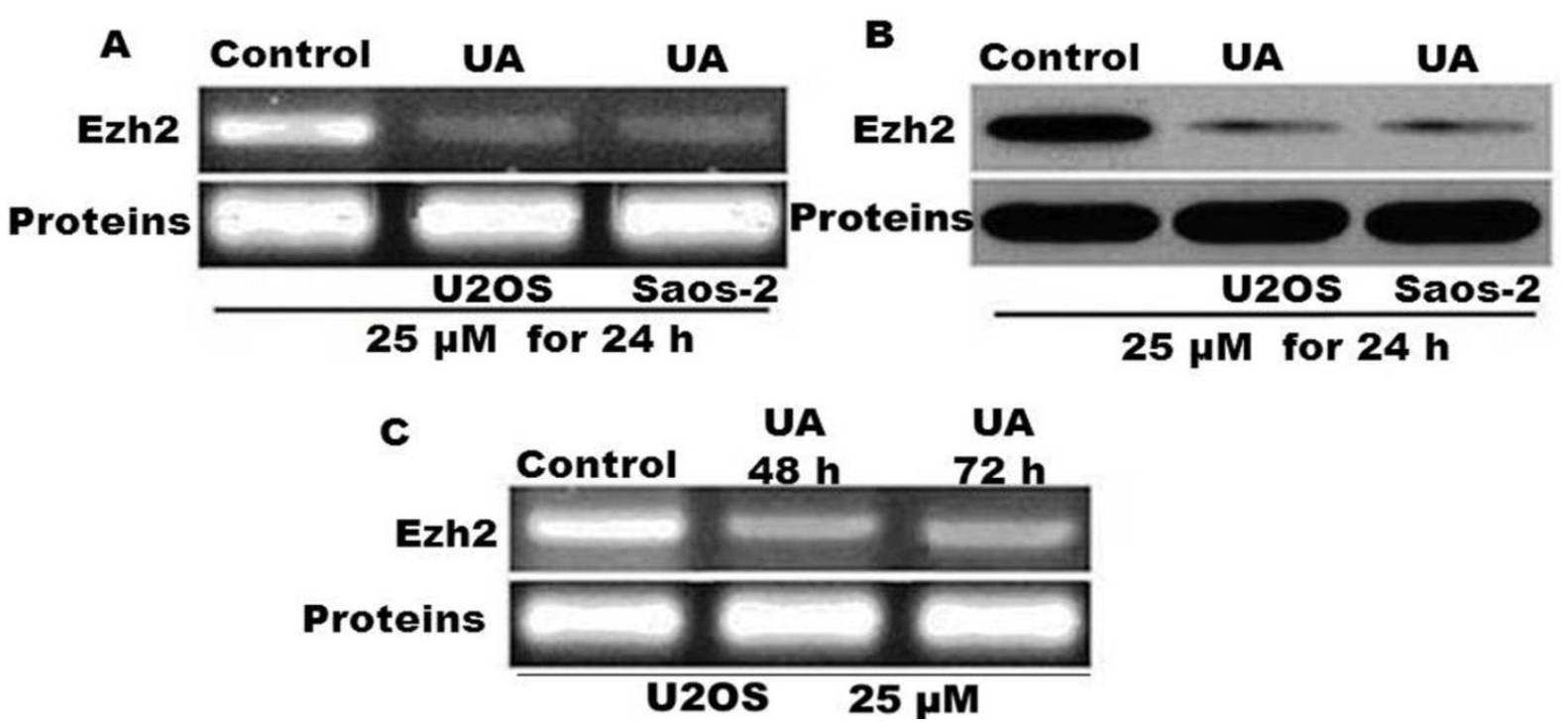

Fig. 3: Expression of Ezh2 and protein in U2OS and Saos-2 cells after UA transfection. (A and C) After the U2OS and Saos-2 cells were transfected with $25 \mu \mathrm{M} \cup A$, the expression level of the Ezh2 and proteins was significantly reduced. (B) The efficacy of UA to inhibit the Ezh2 expression was further analysed by western blotting analysis 
Induction of apoptosis in U2OS and Saos-2 human osteosarcoma cells

In U2OS cells treatment with 10 and $25 \mu \mathrm{M}$ UA induced apoptosis in $5.89 \pm 3.9$ and $60.54 \pm 5.4$ $\%$ cells respectively compared to $2.05 \pm 1.01 \%$ cells in control (Fig. 4). Similar results were observed in Saos-2 cells, where in exposure to 10 and $25 \mu \mathrm{M}$ UA induced apoptosis in $9.86 \pm$ 8.89 and $47.54 \pm 14.5 \%$ cells, respectively, compared to $1.79 \pm 0.23 \%$ in control cells (data not shown).

\section{Induction of apoptosis in the U2OS and Saos- 2 human osteosarcoma cells}

The results clearly showed that increasing in concentration of UA in UA-incorporated GC nanoparticle from 10 to $25 \mu \mathrm{M}$ significantly reduced the mitochondrial membrane potential in U2OS cells (Fig 5A). Western blot analysis revealed translocation of $\mathrm{Bax}$ and $\mathrm{Bcl}-2$ proteins from mitochondria to cell cytosol (Fig 5B). Similar results were obtained in Saos-2 human osteosarcoma cell lines.

\section{Cell cycle arrest in the G0/G1 phase in U2OS and Saos-2 human osteosarcoma cells}

The results from flow cytometry showed a significant increase in G0/G1 cell population in both U2OS and Saos-2 cells with subsequent decrease in $S$ and $G 2 / M$ phase on treatment with UA $(10 \mu \mathrm{M})$ (Fig 6B, D). The increase in concentration of UA from $10 \mu \mathrm{M}$ to $25 \mu \mathrm{M}$ led to further increase in the percentage of cells in G0/G1 phase and subsequent decrease in cell percentage from $S$ and G2/M phase (Fig. 6C, E). These results confirm that UA transfection arrests cell cycle in G0/G1 phase in human osteosarcoma cell lines.

\section{DISCUSSION}

UA-incorporated GC nanoparticles formed by electrostatic interaction between $-\mathrm{COOH}$ group of $\mathrm{UA}$ and $-\mathrm{NH}_{2}$ group of glycol chitosan were prepared. The presence of reactive $-\mathrm{NH}_{2}$ group makes chitosan a suitable substrate for drug conjugation and ion complex formation with anionic drugs [10]. Thünemann and Beyermann initially developed the concept of nanoparticle formation between acid and positively charged macromolecules [23]. The present study demonstrates the effect of UA-incorporated GC nanoparticles on inhibition of osteosarcoma cell proliferation and cell cycle arrest. The results
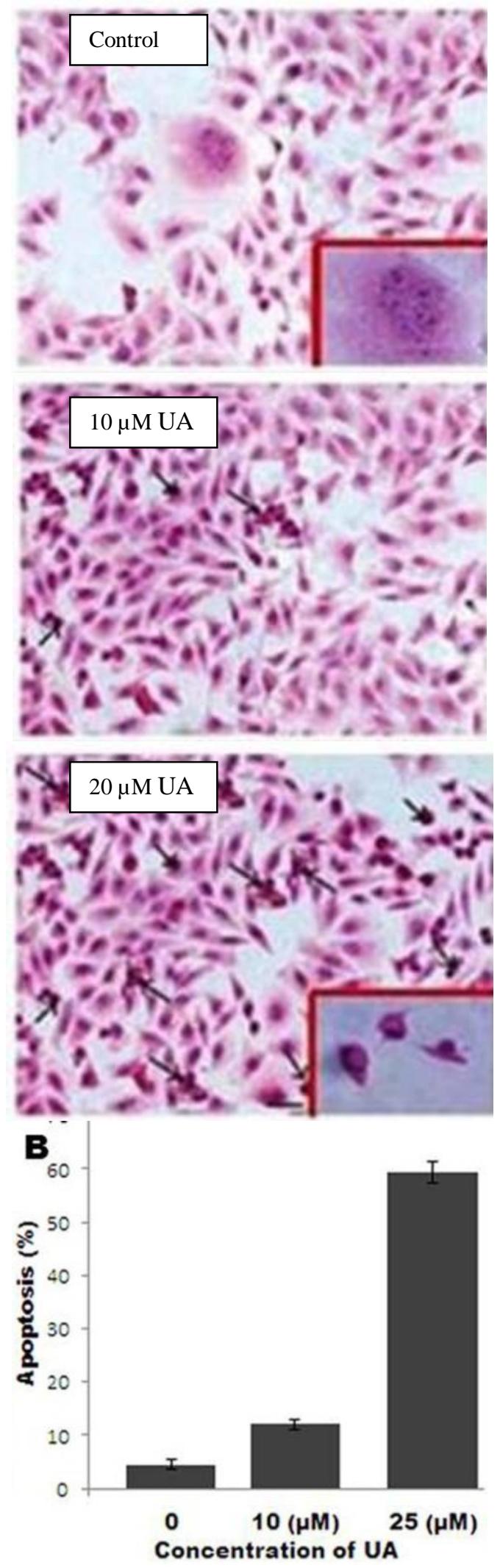

Fig 4: UA-induced apoptosis in U2OS cells. Cultures were grown either in medium containing empty GC vesicles (control) or in a medium containing $10 \mu \mathrm{M}$ or $25 \mu \mathrm{M}$ UA. The arrows indicate apoptotic cells; magnified image of cells was shown in corner 


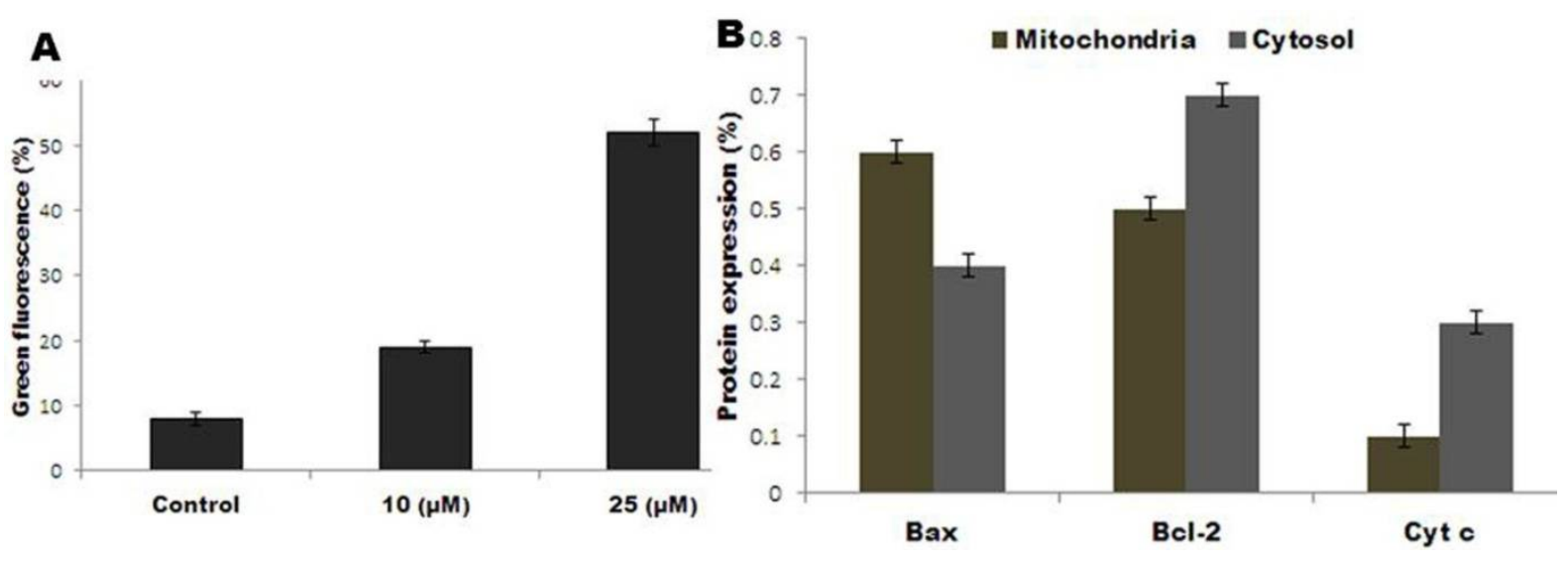

Fig 5: UA induces apoptosis in U2OS cells through the mitochondrial pathway (A) Changes in the mitochondrial membrane potential were analysed by JC-1 staining and subsequent flow cytometry. (B) The expression levels of $\mathrm{Bax}, \mathrm{Bcl}-2$, and cytochrome $\mathrm{c}$ in the cytoplasm and mitochondria were analysed by Western blotting

\section{U20s}
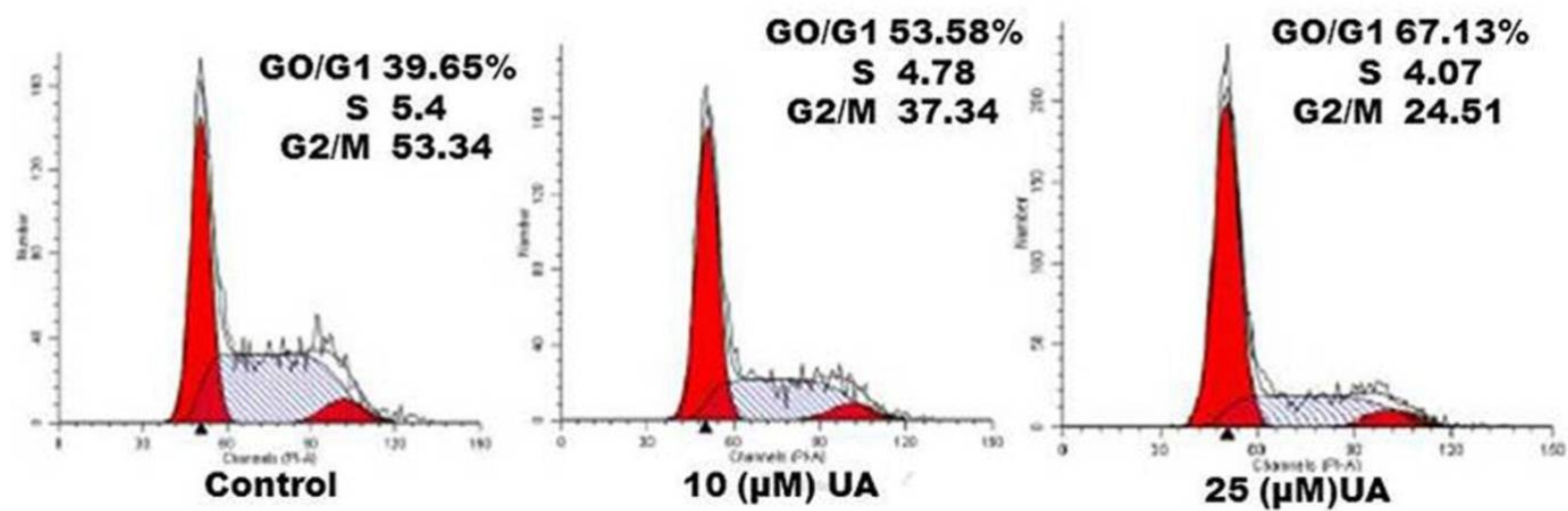

Saos-2
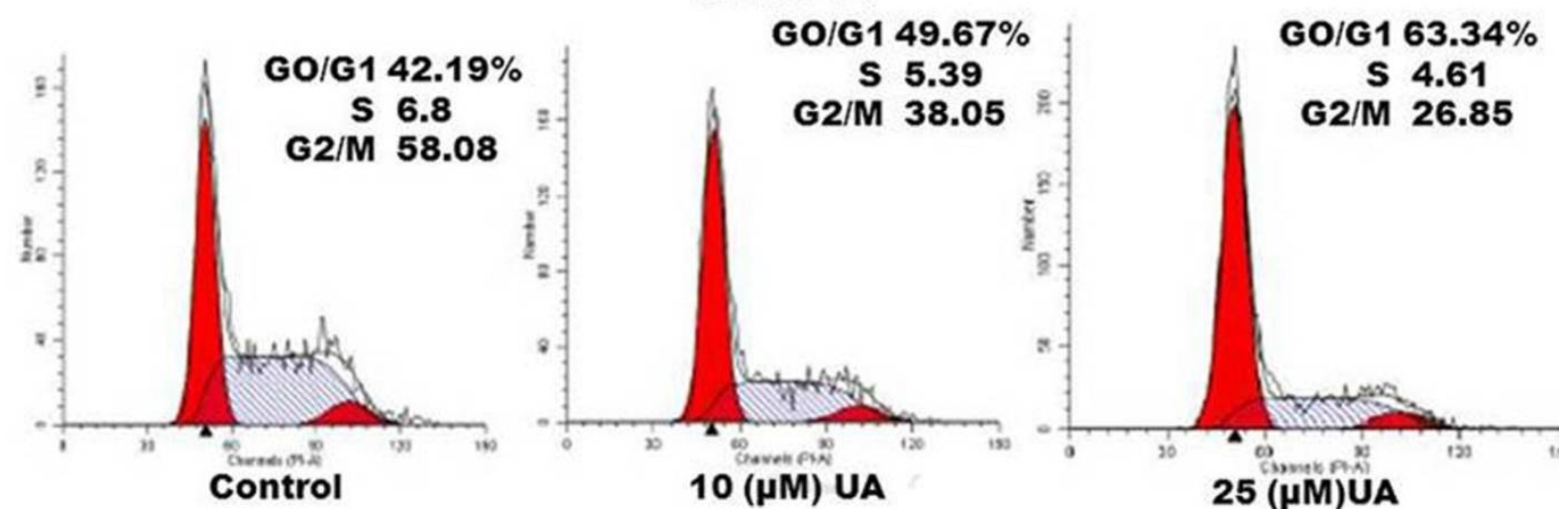

Fig 6: Effect of UA transfection on cell cycle arrest in U2OS and Saos-2 cells. (A) The cell cycle distribution of U2OS and Saos- 2 cells that had been treated with empty GC vesicles. (B, C, D and E) The cell cycle distribution of U2OS and Saos-2 cells that had been treated with 10 and 25 $\mu$ M UA incorporated GC nanoparticles

showed a marked inhibition in cell proliferation on treatment with UA-incorporated GC nanoparticles after $24 \mathrm{~h}$. The proliferation inhibition continued for $72 \mathrm{~h}$ and the effect was seen to be maximum on day 4 .
It has been shown that polycomb group genes are epigenetically associated with the regulation of gene transcription programs during cellular differentiation and development [8]. Ezh2 controls expansion and differentiation of tumor initiating cells and plays an important role in the 
development and progression of cancer [9-11]. The results from the present study revealed that UA transfection in U2OS and Saos-2 human osteosarcoma cells caused inhibition of Ezh2 expression.

The results from apoptosis and necrosis assay showed increase in the percentage of apoptosis on increasing the concentration of UA. It was observed that osteosarcoma cells undergo apoptosis through mitochondrial pathway. The $\mathrm{Bax}$ and $\mathrm{Bcl}-2$ proteins were seen to translocate from mitochondria into cytoplasm where they led to release of cytochrome c. Cytochrome $\mathrm{c}$ then activates caspase 9 and caspase 3 , which play key roles in the apoptosis pathway. The increase in concentration of UA in UA-incorporated GC nanoparticle from $10 \mu \mathrm{M}$ to $25 \mu \mathrm{M}$ significantly reduced the mitochondrial membrane potential in U2OS cells. Therefore, these results suggest that the UA inhibition of Ezh2 expression induces apoptosis through the mitochondrial pathway in human osteosarcoma cells. Our results from flow cytometry also suggest that UA induces cell cycle arrest in G0/G1 phase.

\section{CONCLUSION}

UA induces proliferation inhibition, apoptosis and cell cycle arrest in G0/G1 in osteosarcoma cells via inhibition of Ezh2 expression. Thus, UAincorporated GC nanoparticles may be a promising strategy for the treatment of osteosarcoma.

\section{REFERENCES}

1. Jaffe N. Osteosarcoma: review of the past, impact on the future. The American experience. Cancer Treat Res 2009; 152: 239-262.

2. Janeway K, Gorlick R, Bernstein M. Osteosarcoma. In: Orkin $S$, Fisher $D$, Look $A$, Lux $S$, Ginsburg $D$, Nathan $D$, eds. Oncology of Infancy and Childhood. Philadelphia: Saunders Elsevier 2009: 871-910

3. Marina N, Gebhardt M, Teot L, Gorlick R. Biology and therapeutic advances for pediatric osteosarcoma. Oncologist 2004; 9: 422-441

4. Gorlick R, Toretsky J, Marina N. Bone tumors. In: Kufe D, Pollock $R$, Weichselbaum $R$, et al., eds. Cancer Medicine, 6th ed., Vol. 2. Hamilton, Ontario, Canada: BC Decker 2003; 2383-2406.

5. Marina N, Gorlick R, Bielack S. Pediatric osteosarcoma In: Carroll W, Finlay J, eds. Cancer in Children and Adolecents. Sudbury, MA: Jones and Bartlett 2010; 383-394.

6. Chou AJ, Geller DS, Gorlick R. Therapy for osteosarcoma: where do we go from here? Paediatr Drugs 2008; 10: 315-327.
7. O'Day K, Gorlick R. Novel therapeutic agents for osteosarcoma. Expert Rev Anticancer Ther 2009; 9: 511-523.

8. Müller S, Hoege C, Pyrowolakis G, Jentsch S. SUMO, ubiquitin's mysterious cousin. Nat Rev Mol Cell Biol 2001; 2: 202-210.

9. Geiss-Friedlander $R$, Melchior $F$. Concepts in sumoylation: a decade on. Nat Rev Mol Cell Biol 2007; 8: 947-956.

10. Yeh ET. SUMOylation and De-SUMOylation: wrestling with life's processes. J Biol Chem 2009; 284: 82238227.

11. Kim JH, Baek SH. Emerging roles of desumoylating enzymes. Biochim Biophys Acta 2009; 1792: 155162.

12. Bailey $D$, O'Hare P. Characterization of the localization and proteolytic activity of the SUMO-specific protease, SENP1. J Biol Chem 2004; 279, 692-703.

13. Cheng J, Wang D, Wang Z, Yeh ET. SENP1 enhances androgen receptor-dependent transcription through desumoylation of histone deacetylase 1. Mol Cell Biol 2004; 24: 6021-6028.

14. Itahana $Y$, Yeh ET, Zhang Y. Nucleocytoplasmic shuttling modulates activity and ubiquitination-dependent turnover of SUMO-specific protease 2. Mol Cell Biol 2006; 26: 4675-4689.

15. Zhang H, Saitoh H, Matunis MJ. Enzymes of the SUMO modification pathway localize to filaments of the nuclear pore complex. Mol Cell Biol 2002; 22: 64986508.

16. Zhu YM, Shen JK, Wang HK, Cosentino LM, Lee KH. Synthesis and anti- HIV activity of oleanolic acid derivatives, Bioorg. Med Chem Lett 2001; 11: 31153118.

17. Ma C, Nakamura N, Miyashiro H, Hattori M, Shimotohno $K$. Inhibitory effects of constituents from Cynomorium songaricum and related triterpene derivatives on HIV1 protease, Chem Pharm Bull 1999; 47: 141-145.

18. Liu J. Pharmacology of oleanolic acid and ursolic acid, $J$ Ethnopharmacol 1995; 49: 57-68.

19. Lee $K H$, Lin YM, Wu TS, Zhang DC, Yamagishi T, Hayashi T, Hall IH, Chang JJ, Wu RY, Yang TH. The cytotoxic principles of Prunella vulgaris, Psychotria serpens and Hyptis capitata: ursolic acid and related derivatives, Planta Med 1988; 54: 308-311.

20. Lin CN, Lu CM, Cheng MK, Gan KH, Won SJ. The cytotoxic principles of Solanum incanum, J Nat Prod 1990; 53: 513-516.

21. Pisha E, Chai H, Lee IS, Chagwedera TE, Farnsworth $N R$, Cordell GA, Beencher CW, Fong HH, Kinghorn $A D$, Brown DM, Wani MC, Wall ME, Hieken TJ, Gupta TKD, Pezzuto JM. Discovery of betulinic acid as a selective inhibitor of human melanoma that functions by induction of apoptosis, Nat Med 1995; 1 : 1046-1051.

22. Sun IC, Chen $\mathrm{CH}$, Kashiwada $\mathrm{Y}, \mathrm{Wu} \mathrm{JH}$, Wang HK, Lee $K H$. Anti-AIDS agents: synthesis, anti-HIV and anti- 
fusion activities of IC9564 analogues based on betulinic acid, J Med Chem 2002; 45: 4271-4275.

23. Harmand PO, Duval R, Delage C, Simon A. Ursolic acid induces apoptosis through mitochondrial intrinsic pathway and caspase-3 activation in M4Beu melanoma cells, Int J Cancer 2005; 114; 1-11. 